\title{
Calcium-Induced Freezing and Salinity Tolerance in Evergreen Oak and Apple cv. 'Golden Crown'
}

\author{
Glynn Percival and Sally Barnes
}

\begin{abstract}
Greater variability in weather patterns and later spring frosts equate to poor winter hardiness, premature spring budbreak, and greater susceptibility to low-temperature damage and concomitant deicing salt application. A field trial was undertaken to determine the influence of a range of commercially available calcium fertilizers applied as foliar sprays on the freezing and salinity tolerance of two tree species, evergreen oak (Quercus ilex L.) and apple (Malus cv. 'Golden Crown'). In all cases, application of calcium sprays increased twig, leaf, and root freezing and salt tolerance of both species as measured by leaf chlorophyll fluorescence and tissue electrolyte leakage bioassays. In the case of apple, a hardiness gain of $4.3^{\circ} \mathrm{C}\left(7.74^{\circ} \mathrm{F}\right)$ was recorded in twig tissue. In the case of evergreen oak, a hardiness gain of $2.1^{\circ} \mathrm{C}\left(3.78^{\circ} \mathrm{F}\right)$ was recorded in leaf tissue. After a $-5^{\circ} \mathrm{C}\left(23^{\circ} \mathrm{F}\right)($ apple $)$ and $-6.5^{\circ} \mathrm{C}\left(20^{\circ} \mathrm{F}\right)$ (evergreen oak) freezing stress, root electrolyte leakage values as a measure of cell membrane structural damage were $16 \%$ to $27 \%$ less in calcium-treated trees compared with noncalcium-treated controls. The salt concentration needed to cause $50 \%$ reductions in leaf chlorophyll fluorescence as a measure of photosynthetic efficiency rose by $0.2 \%$ to $1.2 \%$ in calciumfertilized trees indicating a positive influence of calcium on enhancing leaf tissue tolerance to salt damage. Differences in the magnitude of freezing and salinity tolerance gained were noticeable between the calcium products used. In general, calcium hydroxide, calcium nitrate borate, and calcium metalosate improved twig, leaf, and root freezing and salt tolerance in both tree species to a greater degree than calcium chloride, calcium sulphate, calcium nitrate, and a calcium-magnesium complex. A significant correlation existed between increased freezing tolerance and internal tissue calcium content. Results of this study indicate that calcium sprays during late summer and fall can increase the freezing and salinity tolerance of evergreen oak and apple during the winter. This should be considered noteworthy for individuals involved in the management of trees in areas subject to subzero temperature fluctuations and/or concomitant applications of deicing salts in the form of sodium chloride.
\end{abstract}

Key Words. Chlorophyll fluorescence; cold tolerance; electrolyte leakage; fertilizer; landscape management; plant health care; stress.

Aesthetic criteria is an important influence regarding selection of trees for planting within an urban environment with planting schemes along roads, in town centers, car parks, and streets often stylized by distinct forms and preferred flowering and foliage qualities (Percival and Hitchmough 1995). Consequently, trees selected for planting are located outside their normal climatic zones and may not be fully adapted to the climate in which they are being grown. This lack of fitness to climate may be further exacerbated by changes in weather patterns caused by climate change, which is not only likely to result in more mild winters, but also in more variable weather patterns. Milder winters, greater variability in weather patterns, and later spring frosts equate to poor winter hardiness, premature spring budbreak, and greater susceptibility to low-temperature damage. Late spring frosts are particularly devastating, because young spring growth is unable to acclimate (Cannel and Smith 1986). Pertinent examples include $-6^{\circ} \mathrm{C}\left(20^{\circ} \mathrm{F}\right)$ temperatures recorded in early 2007 in California, U.S. causing significant damage to the citrus industry with lemon and orange yield losses greater than $50 \%$ predicted (Anon 2007), whereas freezing temperatures less than $-20^{\circ} \mathrm{C}\left(-4^{\circ} \mathrm{F}\right)$ experienced in Scotland resulted in significant economic damage to the hardy ornamental woody plant industry (Percival et al. 1999).

The application of deicing salts, primarily in the form of sodium chloride, to maintain safe roadways and pavements is a common practice throughout Europe and the United States. Despite the benefits for public safety, deicing salts can be a major chemical pollutant in urban landscapes having a detrimental effect on roadside vegetation (Percival et al. 2003). When deicing salts are deposited directly onto twigs, buds, or needles, salt draws moisture out of plant tissue, causing desiccation and necrosis. In the case of conifers such as cypress, firs, and spruce, salt spray causes dieback starting at the tips of needles. On deciduous trees, symptoms of salt damage become manifest during spring and summer when leaf margins typically display necrosis or scorch symptoms. Salt spray and excess soil salts can also cause branch dieback, stunted growth of stems and foliage, reduced tree vigor, and death (Dobson 1991).

Calcium is a major macronutrient in trees, important to the structural integrity of cell walls and plasma membranes (Steponkus 1984). Calcium has been implicated in resistance to freeze-thaw injury and has been shown to alleviate damage caused by freezing stress to cell membranes (Palta and Li 1980; Palta, 1996). Additionally, low-temperature acclimation can be influenced by the concentration of calcium in the cell cytoplasm (Monroy et al. 1993). Previous research has shown that applications of calcium sprays can improve winter hardiness of fruit trees (Raese 1997) and increase time spent in cold storage of crops such as avocados, mangoes, cherries, and apples (Anderson and Campbell 1995; Raese 1996). In addition, gypsum (calcium sulphate) is widely advocated as a remedial measure to reduce deicing salt injury to plants (Dobson 1991). Commercially, a range of fertilizers exist containing different forms of calcium such as calcium nitrate, calcium sulphate, and calcium 
chloride. These fertilizers are widely used by the orchard industry to reduce fruit disorders such as bitter pit of apples and cork spot of pears (Raese 1997). The efficacy of these calcium fertilizers has not been evaluated for their potential in improving the freezing and salt tolerance of urban trees.

Objectives of this investigation were to determine the effectiveness and feasibility of seven commercially available calcium fertilizers to improve the freezing and salt tolerance of two tree species, apple (Malus cv. 'Golden Crown'; deciduous) and evergreen oak (Quercus ilex L.; evergreen).

\section{MATERIALS AND METHODS}

\section{Plant Material}

The apple trial site consisted of a 1.5 ha $(3.75 \mathrm{ac})$ block of apple (Malus cv. 'Golden Crown') interspersed with individual trees of Malus 'Red Delicious' and 'Gala' as pollinators. Planting distances were based on $3 \mathrm{~m}(9.9 \mathrm{ft})$ by $3 \mathrm{~m}(9.9 \mathrm{ft})$ spacing. The trees were planted in 1979 and trained as an open leader, i.e., bush-shaped tree, by periodically pruning the central leader. All experimental trees had an average height of $2 \pm 0.2 \mathrm{~m}(6.6 \pm 0.7$ $\mathrm{ft})$ with mean butt diameters of $33 \pm 5 \mathrm{~cm}(13.2 \pm 2 \mathrm{in})$. The evergreen oak trial site consisted of a 1 ha $(2.5 \mathrm{ac})$ block of evergreen oak located opposite to the apple trial site. Planting distances were based on $1 \mathrm{~m}(3.3 \mathrm{ft})$ by $1 \mathrm{~m}(3.3 \mathrm{ft})$ spacing. The trees were planted in 2001 and trained to produce a central leader system to an average height of $1.2 \pm 0.15 \mathrm{~m}(4 \pm 0.5 \mathrm{ft})$ with mean butt diameters of $9 \pm 1 \mathrm{~cm}(3.6 \pm 0.4 \mathrm{in})$. The soil of both sites was a sandy loam containing $4 \%$ to $6 \%$ organic matter, $\mathrm{pH}$ of 6.1, available phosphorus, potassium, magnesium, sodium, and calcium were 55.3, 702.4, 188.2, 52.9, and $1888 \mathrm{mg} / \mathrm{L}$ $(0.0001,0.004,0.002,0.0001$, and $0.02 \mathrm{oz} / \mathrm{gal})$. Site management consisted of a $2 \mathrm{~m}(6.6 \mathrm{ft})$ wide weed-free strip beneath the trees maintained with glyphosate (Roundup; Green-Tech, Sweethills Park, Nun Monkton, York, U.K.). Trees were irrigated with undertree impact sprinklers at approximately 10 day intervals throughout the growing season. No supplementary fertilization was applied during the trial. In the case of apple, a minimal fungicide (myclobutanil, product name Systhane [Landseer Ltd., Chelmsford, Essex, U.K.]) and insecticide (deltamethrin, product name Bandu; Headland Agrochemicals Ltd., Saffron Walden, Essex, U.K.) program was applied every 2 months during the growing season beginning in May 2004 (Nicholas et al. 2003), a standard practice followed at the University of Reading experimental site for orchard pest and disease control. All sprays were applied using a Tom Wanner Spray Rig sprayer (Wanner Engineering, Inc., Minneapolis, MN) at $30 \mathrm{~mL}(0.9 \mathrm{fl} \mathrm{oz})$ myclobutanil $+40 \mathrm{~mL}(1.2 \mathrm{fl} \mathrm{oz})$ deltamethrin per $100 \mathrm{~L}$ (26 gal) of water. Trees were sprayed until runoff, generally $3.5 \mathrm{~L}$ (0.91 gal) per tree. All studies were conducted at Reading University, Shinfield experimental research site, Reading, Berkshire $\left(51^{\circ} 43^{\prime} \mathrm{N}\right.$, $\left.-1^{\circ} 08^{\prime} \mathrm{W}\right)$.

\section{Calcium Treatments}

A randomized complete block was used in the experimental design. Nine treatments (seven calcium products: calcium chloride, calcium sulphate, calcium nitrate, calcium nitrate borate, calcium hydroxide, calcium metalosate, calcium magnesium complex [United Agri-Products, Alconbury Weston, Huntingdon, U.K.]; 1 Silwett L77 [an 80\% polyalkylene oxide $20 \%$ allyloxypolyethylene glycol methyl ether plant penetrant; De
Sangosse, Swaffham Bulbeck, Cambridge U.K.]; and a water control) were assigned to eight single tree replications giving a total of 72 observations per response variable. Calcium sprays were applied using a $5 \mathrm{~L}$ (1.3 gal) pump action sprayer and trees were sprayed until runoff. Single-row borders prevented overspray of calcium treatments and double-row borders prevented calcium drift. Calcium treatments were applied on 15 July, 1 August, 18 August, and 15 September 2004. Each calcium spray was calibrated so that each tree received $2 \mathrm{~g}(0.07 \mathrm{oz})$ calcium per spray ( $8 \mathrm{~g}[0.28 \mathrm{oz}]$ in total). Poor absorption and uptake of foliar applied calcium is a widely recognized problem within the orchard industry. Consequently, calcium sprays are routinely applied in combination with a plant penetrant such a Silwett L77. Silwett L77 was applied singly and in combination with all calcium fertilizers at the manufacturer's recommended rate, $0.5 \mathrm{~mL}$ (0.015 fl oz) per liter (0.26 gal).

\section{Freezing Treatments}

Treatments were carried out during the fall and winter (18 December 2004, 18 January 2005, 9 February 2005). In the case of evergreen oak, six fully expanded nonsenescing leaves per tree were selected at random from throughout the canopy and excised at the base of the petiole using a razor blade and placed abaxial surface down in a Petri dish on moist Watmans filter paper (Cole-Parmer Instrument Company, Ltd., Hanwell, London) sealed with a thin polythene film permeable to air but not water. In the case of apple, because no leaves were present on the tree at each sampling date, $3 \mathrm{~cm}$ (1.2 in) stem sections, three sections per tree selected at random from throughout the canopy, were placed into $50 \mathrm{~mL}$ (1.5 fl oz) Universal bottles (Fisher Scientific, Loughborough, Leicestershire, U.K.) containing $30 \mathrm{~mL}(0.9 \mathrm{fl}$ $\mathrm{oz}$ ) distilled water of a known conductivity and gently shaken by hand. All leaf and stem samples were placed in darkness in a programmable Merck Environmental Freezing Chamber (Merck Pharmaceuticals, West Drayton, Middlesex, U.K.). The temperature was reduced by $2^{\circ} \mathrm{C}\left(3.6^{\circ} \mathrm{F}\right)$ per $\mathrm{hr}$ from $10^{\circ} \mathrm{C}\left(50^{\circ} \mathrm{F}\right)$ and maintained for $4 \mathrm{hr}$ at a set temperature, after which the temperature was raised by $2^{\circ} \mathrm{C}\left(3.6^{\circ} \mathrm{F}\right)$ per $\mathrm{hr}$ to $10^{\circ} \mathrm{C}\left(50^{\circ} \mathrm{F}\right.$; Sakai and Larcher 1987). A series of minimum set temperatures was selected to bracket the temperature causing 50\% electrolyte leakage from stem and leaf tissue. In the case of leaf tissue derived from evergreen oak, set temperature treatments ranged from $2^{\circ} \mathrm{C}$ $\left(3.6^{\circ} \mathrm{F}\right)$ to $-12^{\circ} \mathrm{C}\left(10^{\circ} \mathrm{F}\right)$. In the case of twig tissue derived from apple, set temperature treatments ranged from $-24^{\circ} \mathrm{C}\left(-11^{\circ} \mathrm{F}\right)$ to $-40^{\circ} \mathrm{C}\left(-39^{\circ} \mathrm{F}\right)$. To clarify, in the case of evergreen oak, each individual freezing treatment required six leaves per tree, eight trees per calcium treatment. i.e., 48 leaves in total per freezing $\left(2^{\circ} \mathrm{C}\left[3.6^{\circ} \mathrm{F}\right], 0^{\circ} \mathrm{C}\left[32^{\circ} \mathrm{F}\right],-2^{\circ} \mathrm{C}\left[28^{\circ} \mathrm{F}\right],-4^{\circ} \mathrm{C}\left[25^{\circ} \mathrm{F}\right],-6^{\circ} \mathrm{C}\right.$ $\left.\left[21^{\circ} \mathrm{F}\right],-8^{\circ} \mathrm{C}\left[18^{\circ} \mathrm{F}\right],-10^{\circ} \mathrm{C}\left[14^{\circ} \mathrm{F}\right],-12^{\circ} \mathrm{C}\left[10^{\circ} \mathrm{F}\right]\right)$ treatment. In the case of apple, each individual freezing treatment required three twig sections per tree, eight trees per calcium treatment, i.e., 24 twigs in total per freezing $\left(-24^{\circ} \mathrm{C}\left[-11^{\circ} \mathrm{F}\right],-26^{\circ} \mathrm{C}\right.$ $\left[-15^{\circ} \mathrm{F}\right],-28^{\circ} \mathrm{C}\left[-18^{\circ} \mathrm{F}\right],-30^{\circ} \mathrm{C}\left[-22^{\circ} \mathrm{F}\right],-32^{\circ} \mathrm{C}\left[-26^{\circ} \mathrm{F}\right],-34^{\circ} \mathrm{C}$ $\left.\left[-30^{\circ} \mathrm{F}\right],-36^{\circ} \mathrm{C}\left[-34^{\circ} \mathrm{F}\right],-38^{\circ} \mathrm{C}\left[-38^{\circ} \mathrm{F}\right],-40^{\circ} \mathrm{C}\left[-42^{\circ} \mathrm{F}\right]\right)$ treatment. All leaf and stem material was prepared within $2 \mathrm{hr}$ of collection from the field.

Root samples of both tree species were collected and prepared as described by McKay (1992) before placing into $50 \mathrm{~mL} \mathrm{(1.5} \mathrm{fl}$ oz) Universal bottles containing $30 \mathrm{~mL}(0.9 \mathrm{fl} \mathrm{oz})$ distilled water of a known conductivity. As a result of the problems of obtaining consistency in root sampling size, it was not possible to prepare 
a series of minimum temperatures to bracket the temperature causing 50\% electrolyte leakage. Consequently, root samples were placed in darkness in a programmable Merck Environmental Freezing Chamber and the temperature was reduced by $2^{\circ} \mathrm{C}$ $\left(3.6^{\circ} \mathrm{F}\right)$ per $\mathrm{hr}$ from $10^{\circ} \mathrm{C}\left(50^{\circ} \mathrm{F}\right)$ to $-5^{\circ} \mathrm{C}\left(23^{\circ} \mathrm{F}\right)$ (apple) and $-6.5^{\circ} \mathrm{C}\left(20^{\circ} \mathrm{F}\right)$ (evergreen oak) and maintained for $4 \mathrm{hr}$ after which the temperature was raised by $2^{\circ} \mathrm{C}\left(3.6^{\circ} \mathrm{F}\right)$ per hr to $10^{\circ} \mathrm{C}$ $\left(50^{\circ} \mathrm{F}\right)$. These temperature treatments have been shown to correspond to approximately $50 \%$ electrolyte leakage from root tissue of each species (Percival unpublished data; Kozlowski et al. 1991). Root freezing treatments were carried out on 18 January 2005 only.

\section{Salt Treatments}

Treatments were performed on 17 December 2004, 17 January 2005, and 8 February 2005. Six fully expanded nonsenescing leaves per tree selected at random from throughout the canopy were excised at the base of the petiole using a razor blade. On arrival at the laboratory (less than $2 \mathrm{hr}$ after collection), leaves were immersed in a series of percentage salt $(\mathrm{NaCl})$ solution $(0 \%$ to $12 \%$ ) for $5 \mathrm{~min}$ to select a concentration resulting in $50 \%$ damage to the leaf photosynthetic system as measured by leaf chlorophyll fluorescence Fv/Fm values. After salt immersion, leaves were placed, abaxial surface down, in a Petri dish on moist Watmans filter paper sealed with a thin polythene film permeable to air but not water. After all treatments, leaf samples were placed in a Merck Environmental Growth Chamber in darkness at $22^{\circ} \mathrm{C}\left(72^{\circ} \mathrm{F}\right)$ for $72 \mathrm{hr}$, a time after which saltinduced detrimental effects on chlorophyll fluorescence, values could be detected (Greaves and Wilson 1987). In the case of evergreen oak, each salt treatment $(0 \%, 2 \%, 4 \%, 6 \%, 8 \%, 10 \%$, $12 \%$ ) required six leaves per tree, eight trees per calcium treatment, 48 leaves in total, i.e., 48 leaves were immersed in a zero salt solution, a separate 48 leaves immersed in a $2 \%$ salt solution, and so on until a $12 \%$ salt solution was reached.

\section{Physiological Tests}

All physiological measurements taken during the trial were obtained from existing leaf material on the plant at the initiation of the experiment. Because leaf chlorophyll fluorescence is noninvasive and nondestructive, after each measurement, the same evergreen oak leaves were used to obtain electrolyte leakage values. Electrolyte leakage tests were not conducted on $\mathrm{NaCl}-$ treated plants. The principle of electrolyte leakage is well known. When healthy plant tissue is immersed in ion-free water, there is a slight leakage into the surrounding water that can be detected and quantified using a conductivity meter. If the cell membrane is ruptured because of adverse environmental stress, the cell ion contents leak at a greater rate and therefore conductivity readings are higher. However, electrolyte leakage is not recommended when quantifying tolerance to salt stress because contamination by $\mathrm{NaCl}$ ions within leaf tissue or on the leaf surface can influence these values. Consequently, electrolyte leakage is not considered a good measure of $\mathrm{NaCl}$ damage and therefore not used in this study.

\section{Chlorophyll Fluorescence}

Immediately after the freezing treatment and $72 \mathrm{hr}$ postsalinity treatments, leaves were adapted to darkness for $30 \mathrm{~min}$ by attaching light exclusion clips to the leaf surface and chlorophyll fluorescence was measured using a HandyPEA portable fluorescence spectrometer (Hansatech Instruments Ltd., King's Lynn, U.K.). Measurements were recorded up to $1 \mathrm{sec}$ with a data acquisition rate of $10 \mu \mathrm{s}$ for the first $2 \mathrm{~ms}$ and of $1 \mathrm{~ms}$ thereafter. The fluorescence responses were induced by a red (peak at 650 $\mathrm{nm}$ ) light of $1500 \mu \mathrm{mol} / \mathrm{m}^{-2} / \mathrm{Hz}^{-1}$ photosynthetically active radiation intensity provided by an array of six light-emitting diodes. The ratio of variable $(\mathrm{Fv}=\mathrm{Fm}-\mathrm{Fo})$ to maximal $(\mathrm{Fm})$ fluorescence, i.e., Fv/Fm where Fo $=$ minimal fluorescence, of dark-adapted leaves were used to quantify the detrimental effects of freezing and salinity on leaf tissue. Fv/Fm is considered a quantitative measure of the maximal or potential photochemical efficiency and optimal quantum yield of photosystem II (Willits and Peet 2001). Likewise, Fv/Fm values are the most popular index used as a measure of plant vitality and early diagnostic of stress in plants (Meinander et al. 1996).

\section{Leaf Electrolyte Leakage}

After freezing, samples were stored at $22^{\circ} \mathrm{C}\left(72^{\circ} \mathrm{F}\right)$ for $24 \mathrm{hr}$ in darkness before conductivity measurements using a Jenway conductivity probe and M4070 m (BDH, Leicestershire, Loughborough, U.K.). Total solute leakage was obtained by autoclaving for $1 \mathrm{hr}$ at $121^{\circ} \mathrm{C}\left(249^{\circ} \mathrm{F}\right)$ and $0.103 \mathrm{MPa}$. Results are presented as percent solute leakage after $24 \mathrm{hr}$ (McKay 1992).

\section{Twig and Leaf Calcium Analysis}

Ten leaf and six twig samples per tree were selected at random from throughout the canopy and pooled to form sufficient material for calcium analysis. Samples were then thoroughly washed and dried in a convection oven at $85^{\circ} \mathrm{C}\left(185^{\circ} \mathrm{F}\right)$ for $48 \mathrm{hr}$ before grinding through a $0.5 \mathrm{~mm}$ (0.02 in) cyclone mill (Retsch, Middlesborough, U.K.). Each separate sample (0.5 g [0.02 oz]) was placed into $150 \mathrm{~mL}(4.5 \mathrm{fl} \mathrm{oz})$ volumetric flasks and digested in $20 \mathrm{~mL}(0.6 \mathrm{fl} \mathrm{oz})$ of 7:1 nitric/perchloric acid. After cooling, the solutions were brought to volume with deionized water and analyzed by inductively coupled plasma-emission spectroscopy elemental analysis. Nutrient values were expressed as percent tissue dry weight. Measurements were made on twig and leaf tissue taken at the third sampling date only ( 9 February 2005). The foliar and twig calcium concentration of each tree was correlated with the freezing temperature causing $50 \%$ electrolyte leakage $\left(\mathrm{LT}_{50}\right)$ from stem tissue of apple and leaf tissue of evergreen oak derived from the same tree.

\section{Data Analysis}

Freezing and salt resistance was calculated for each calcium treatment as follows. Electrolyte leakage (percent values) and chlorophyll fluorescence Fv/Fm values were plotted against the treatment temperature and a classic logistic function was fitted to the viability data using slide write software. The temperature at $50 \%$ damage $\left(\mathrm{LT}_{50}\right)$ was calculated for each tree as a parameter of the logistic function that was read from the curve fitting protocol. Each $\mathrm{LT}_{50}$ value per tree (eight trees per calcium treatment) was subjected to a one-way analysis of variance and when significant differences were found $(P<0.05)$, means were compared using the Duncan multiple range test. Levene's (1960) test was used to determine the homogeneity of variances, and percentage data were transformed using arcsine (sqrt [y/100]). Each species was independently statistically analyzed. The influence of sampling date, i.e., time, was initially analyzed as a posttreatment variable. In only one instance (leaf salinity of evergreen oak) was time shown to have a significant influence. Conse- 
Table 1. The influence of calcium spray fertilization on the freezing temperature $\left({ }^{\circ} \mathrm{C}\right)$ causing $50 \%$ electrolyte leakage $\left(\mathrm{LT}_{50}\right)$ from stem tissue of apple (Malus cv. Golden Crown) growing under field conditions. ${ }^{2}$

\begin{tabular}{llll}
\hline Treatment & 18 December 2004 & 18 January 2005 & 9 February 2005 \\
\hline Control & $-27.4(-17)$ & $-30.8(-24)$ & $-31.0(-24)$ \\
Silwett & $-27.8(-18)$ & $-30.8(-24)$ & $-30.5(-23)$ \\
Calcium chloride & $-30.6^{*}(-23)$ & $-34.1^{*}(-30)$ & $-32.5(-27)$ \\
Calcium sulphate & $-29.9(-22)$ & $-32.1(-26)$ & $-32.2(-26)$ \\
Calcium nitrate & $-29.6(-22)$ & $-31.2(-24)$ & $-32.4(-27)$ \\
Calcium nitrate borate & $-30.8^{*}(-24)$ & $-33.9^{*}(-30)$ & $-33.5^{*}(-29)$ \\
Calcium hydroxide & $-31.7^{*}(-26)$ & $-34.0^{*}(-30)$ & $-34.6^{*}(-31)$ \\
Calcium metalosate & $-31.1^{*}(-24)$ & $-32.7(-27)$ & $-34.8^{*}(-32)$ \\
Calcium-magnesium complex & $-28.7(-20)$ & $-31.5(-26)$ & $-33.7^{*}(-30)$
\end{tabular}

${ }^{\mathrm{z}}$ Means that are significantly different from the control using Duncan's multiple range test $(P=0.05)$ are indicated with an asterisk.

All values mean of eight trees, three stems per tree.

Values in parenthesis $={ }^{\circ} \mathrm{F}$ (two significant figures).

quently, the statistical program was restricted independently to each sampling date to compare controls against calcium-treated values. Spearman rank order correlation was used to determine the relationship between freezing damage and twig and leaf tissue calcium content at the third sampling date (9 February 2005).

\section{RESULTS}

\section{The Influence of Calcium on Twig and Leaf Freezing Tolerance}

Both apple and evergreen oak showed only minor changes in twig and leaf freezing hardiness throughout the three sampling dates as control $\mathrm{LT}_{50}$ values varied by only $3^{\circ} \mathrm{C}\left(5^{\circ} \mathrm{F}\right)$ (twig tissue; Table 1$)$ and $0.8^{\circ} \mathrm{C}\left(1.4^{\circ} \mathrm{F}\right)$ (leaf tissue; Table 2). Irrespective of species, no significant influence of the plant penetrant Silwett L77 used to facilitate entry of calcium ions into the leaf was recorded because $\mathrm{LT}_{50}$ values were, in all cases, not significantly $(P<0.05)$ different from controls (Tables 1 and 2$)$.

In both tree species and on all three sampling dates, the freezing temperature required to cause $50 \%$ electrolyte leakage was constantly lower in calcium-treated trees, indicating a positive influence of calcium on enhancing twig and leaf tissue tolerance to freezing damage (Tables 1 and 2). In the case of apple, the freezing tolerance of twig tissue was enhanced by $4.3^{\circ} \mathrm{C}\left(7.7^{\circ} \mathrm{F}\right)$ on the first sampling date (18 December 2004$), 3.3^{\circ} \mathrm{C}\left(5.9^{\circ} \mathrm{F}\right)$ on

Table 2. The influence of calcium spray fertilization on the freezing temperature $\left({ }^{\circ} \mathrm{C}\right.$ ) causing $50 \%$ electrolyte leakage $\left(\mathrm{LT}_{50}\right)$ from leaf tissue of evergreen oak (Quercus ilex L.) growing under field conditions. ${ }^{2}$

\begin{tabular}{llll}
\hline Treatment & 18 December & 18 January & $\begin{array}{l}\text { 9 February } \\
2005\end{array}$ \\
\hline Control & 2004 & 2005 & 2005 \\
Silwett & $-5.5(22)$ & $-6.2(21)$ & $-5.7(22)$ \\
Calcium chloride & $-5.7(22)$ & $-5.9(21)$ & $-5.4(22)$ \\
Calcium sulphate & $-6.2^{*}(21)$ & $-6.8^{*}(20)$ & $-7.2^{*}(19)$ \\
Calcium nitrate & $-5.7(22)$ & $-7.1^{*}(19)$ & $-7.1^{*}(19)$ \\
Calcium nitrate borate & $-6.7^{*}(20)$ & $-6.9^{*}(20)$ & $-6.5^{*}(20)$ \\
Calcium hydroxide & $-7.6^{*}(18)$ & $-7.6^{*}(18)$ & $-6.7^{*}(20)$ \\
Calcium metalosate & $-6.9^{*}(20)$ & $-7.7^{*}(18)$ & $-7.7^{*}(18)$ \\
Calcium-magnesium complex & $-5.9^{*}(21)$ & $-6.4(21)$ & $-7.3^{*}(19)$ \\
\hline
\end{tabular}

${ }^{\mathrm{z}}$ Means that are significantly different from the control using Duncan's Multiple Range Test $(P=0.05)$ are indicated with an asterisk.

All values mean of eight trees, six leaves per tree.

Values in parenthesis $={ }^{\circ} \mathrm{F}$ (two significant figures). the second sampling date (18 January 2005$)$, and $3.8^{\circ} \mathrm{C}\left(6.8^{\circ} \mathrm{F}\right)$ on the final sampling date (9 February 2005; Table 1). In the case of evergreen oak, the freezing tolerance of leaf tissue was enhanced by $2.1^{\circ} \mathrm{C}\left(3.8^{\circ} \mathrm{F}\right)$ on the first sampling date, $1.5^{\circ} \mathrm{C}\left(2.7^{\circ} \mathrm{F}\right)$ on the second sampling date, and $2^{\circ} \mathrm{C}\left(3.6^{\circ} \mathrm{F}\right)$ on the final sampling date (Table 2). In the majority of cases, these increases in freezing tolerance were significant at $P<0.05$ (Tables 1 and 2). Differences in the magnitude of freezing tolerance conferred were observed between each calcium fertilizer. In general, calcium hydroxide, calcium chloride, calcium nitrate borate, and calcium metalosate improved freezing tolerance of both apple and English oak to a greater degree than all other calcium fertilizers tested (Tables 1 and 2).

\section{The Influence of Calcium on Root Freezing Tolerance}

In virtually all cases, the root freezing tolerance of apple and evergreen oak was significantly $(P<0.05)$ enhanced by calcium fertilization (Figure 1). In the case of apple, damage to root cellular membranes as assessed by electrolyte leakage after a $-5^{\circ} \mathrm{C}\left(23^{\circ} \mathrm{F}\right)$ freezing temperature was reduced by $18 \%$ to $26 \%$ with calcium hydroxide and nitrate borate conferring the greatest degree of freezing tolerance. In the case of evergreen oak, root electrolyte leakage values were reduced by $16 \%$ to $27 \%$ compared with noncalcium-treated controls after a $-6.5^{\circ} \mathrm{C}\left(20^{\circ} \mathrm{F}\right)$ freezing temperature. Greatest increases in root freezing tolerance of evergreen oak were conferred by application of calcium sulphate, calcium nitrate, calcium hydroxide, and calcium metalosate. All results indicate a positive influence of calcium on enhancing root tissue to freezing damage. No significant influence of the plant penetrant Silwett L77 on root freezing tolerance was recorded (Figure 1).

\section{The Influence of Calcium on Leaf Salinity Tolerance of Evergreen Oak}

A trend toward increasing salt hardiness with time (December to February) was observed (Table 3 ). The salt concentration causing $50 \%$ reductions in leaf photosynthetic efficiency in controls as measured by chlorophyll fluorescence rose from $7.3 \%$ in December to $8.3 \%$ in January to $8.6 \%$ in February. No significant influence on salt hardiness was recorded after application of Silwett L77 (Table 3). On all three sampling dates, the salt concentration required to cause $50 \%$ reduction in chlorophyll fluorescence was higher in calcium-treated trees with one ex- 


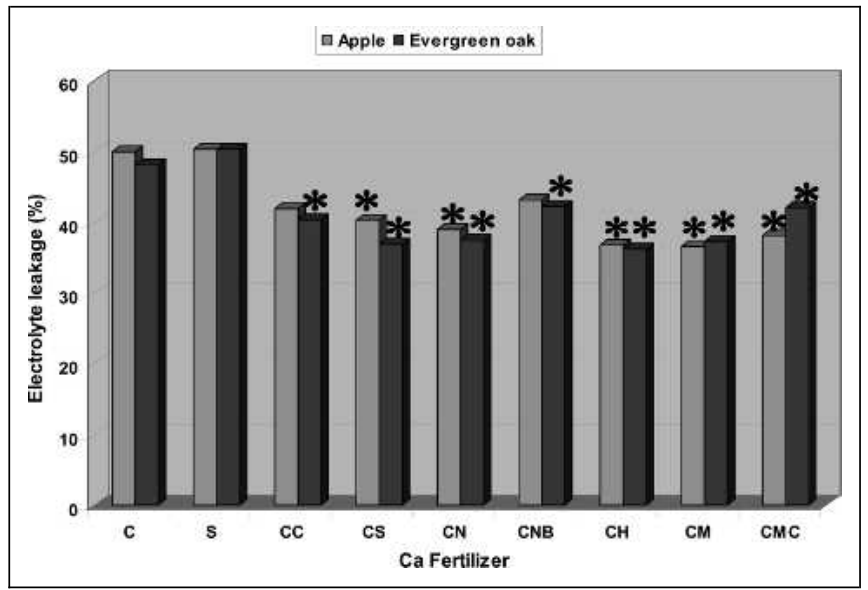

Figure 1. The influence of calcium spray fertilization on electrolyte leakage values from root tissue of apple (Malus cv. 'Golden Crown') and evergreen oak (Quercus ilex L.) growing under field conditions following $a-5^{\circ} \mathrm{C}\left(23^{\circ} \mathrm{F}\right.$; apple) and $-6.5^{\circ} \mathrm{C}\left(20^{\circ} \mathrm{F}\right.$; evergreen oak) freezing treatment. Means that are significantly different from the control using Duncan's multiple range test $(P=0.05)$ are indicated with an asterisk. All values mean of eight trees, three root samples per tree. $C$ = control; $\mathrm{S}=$ Silwett L77; CC = calcium chloride; $\mathrm{CS}$ = calcium sulphate; $\mathrm{CN}=$ calcium nitrate; $\mathrm{CNB}=$ calcium nitrate borate; $\mathrm{CH}=$ calcium hydroxide; $\mathrm{CM}=$ calcium metalosate; $\mathrm{CMC}=$ calcium-magnesium complex.

ception, calcium sulphate on the third sampling date (9 February 2005) in which $\mathrm{LT}_{50}$ values were equivalent to controls (Table 3 ). The salt concentration needed to cause $50 \%$ reductions in leaf chlorophyll fluorescence rose by between $0.4 \%$ and $1.2 \%$ in December $2004,0.2 \%$ to $1.2 \%$ (January 2005), and $0.0 \%$ to $0.9 \%$ in February 2005 indicating a positive influence of calcium on enhancing leaf tissue tolerance to salt damage. Although application of calcium in all cases enhanced the foliar salt tolerance of evergreen oak, in not every instance were these increases significant $(P<0.05)$ from controls (Table 3$)$. Differences in the magnitude of foliar salt tolerance recorded depended on the calcium fertilizer applied. For example, calcium hydroxide induced the greatest degree of tolerance compared with all other calcium fertilizers tested (Table 3).

Table 3. The influence of calcium spray fertilization on the salt $(\mathrm{NaCl})$ concentration causing $50 \%$ reducing in leaf photosynthetic efficiency as measured by chlorophyll fluorescence Fv/Fm values of evergreen oak (Quercus ilex L.) growing under field conditions. ${ }^{2}$

\begin{tabular}{llll}
\hline & $\begin{array}{l}17 \text { December } \\
\text { Treatment }\end{array}$ & $\begin{array}{l}\text { 17 January } \\
2004\end{array}$ & $\begin{array}{l}8 \text { February } \\
2005\end{array}$ \\
\hline Control & 7.8 & 8.3 & 8.6 \\
Silwett & 7.5 & 8.1 & 8.5 \\
Calcium chloride & $9.0^{*}$ & 8.8 & 8.6 \\
Calcium sulphate & 8.3 & 8.5 & $9.2^{*}$ \\
Calcium nitrate & $8.7^{*}$ & $9.2^{*}$ & $9.1^{*}$ \\
Calcium nitrate borate & 8.2 & $8.9^{*}$ & $9.5^{*}$ \\
Calcium hydroxide & $9.0^{*}$ & $9.5^{*}$ & $9.5^{*}$ \\
Calcium metalosate & 8.3 & 8.3 & $9.3^{*}$ \\
Calcium-magnesium complex & $8.8^{*}$ & 8.8 & $9.2^{*}$
\end{tabular}

${ }^{\mathrm{z}}$ Means that are significantly different from the control using Duncan's multiple range test $(P=0.05)$ are indicated with an asterisk.

All values mean of eight trees, six leaves per tree.

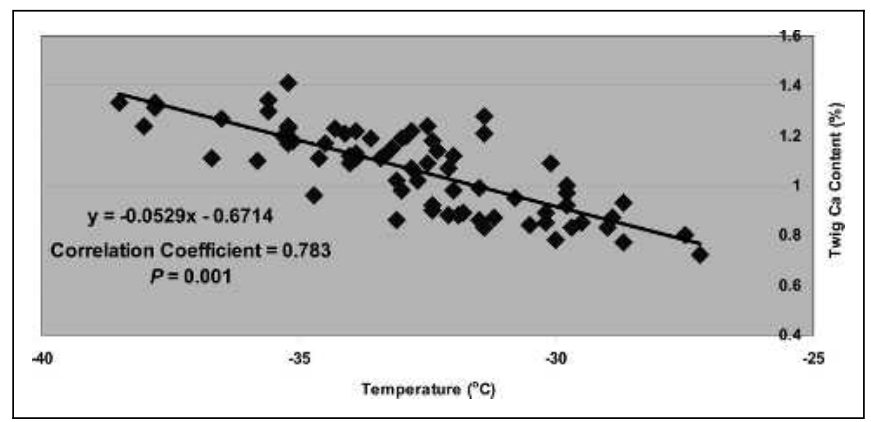

Figure 2. Calibration curve and correlation coefficient of twig calcium content and the freezing temperature causing $50 \%$ electrolyte leakage $\left(\mathrm{LT}_{50}\right)$ from stem tissue of apple (Malus cv. 'Golden Crown') growing under field conditions. Figure 2 shows combined data for all nine treatments (seven calcium products, nine Silwett $\mathrm{L77}$ and a water control), eight trees per treatment, 72 observations per response variable.

\section{Correlation Coefficient of Twig (apple) and Leaf (evergreen oak) Calcium Content and $50 \%$ Electrolyte Leakage Freezing Temperature}

A high correlation between internal twig and leaf tissue calcium content and the freezing temperature required to cause $50 \%$ electrolyte leakage was recorded (Figures 2 and 3). Correlation coefficients were 0.783 (apple) and 0.769 (evergreen oak) and in both cases highly significant at $P=0.001$. These results indicate the higher the internal tissue calcium content, the greater the tolerance to freezing stresses.

\section{DISCUSSION}

Results of this investigation support the suggestion that calcium fertilization can improve the freezing and salinity tolerance of trees. Gains in freezing tolerance ranged from $0.4^{\circ} \mathrm{C}$ to $4.3^{\circ} \mathrm{C}$ $\left(0.72^{\circ} \mathrm{F}\right.$ to $\left.7.7^{\circ} \mathrm{F}\right)$ in calcium-treated twig tissue of apple and from $0.2^{\circ} \mathrm{C}$ to $2.1^{\circ} \mathrm{C}\left(0.36^{\circ} \mathrm{F}\right.$ to $\left.3.8^{\circ} \mathrm{F}\right)$ in calcium-treated leaf tissue of evergreen oak. Similar gains in freezing tolerance of apple and pear trees after calcium fertilization were reported by Raese (1996) in extensive trials carried out in six orchards throughout Washington State. Likewise, work by Percival and Barnes (2005) reported an increase in the freezing and salinity tolerance of evergreen oak (Quercus ilex) and holly (Ilex aqui-

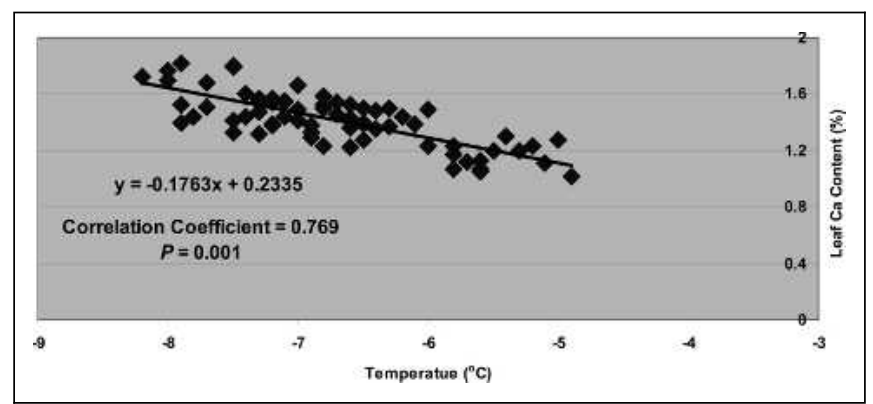

Figure 3. Calibration curve and correlation coefficient of leaf calcium content and the freezing temperature causing $\mathbf{5 0} \%$ electrolyte leakage ( $\mathrm{LT}_{50}$ ) from leaf tissue of evergreen oak (Quercus ilex L.) growing under field conditions. Figure 3 shows combined data for all nine treatments (seven calcium products, one Silwett L77 and a water control), eight trees per treatment, 72 observations per response variable. 
folium) as measured by leaf chlorophyll fluorescence, electrolyte leakagen and chlorophyll content after fall fertilization with calcium nitrate and calcium nitrate borate. Such an increase in tolerance was not shown by autumn application of nitrogen alone indicating a positive role for calcium ions in enhancing plant freezing and salt tolerance. In addition, improvements in the freezing and chilling tolerance of landscape trees such as hornbeam and white poplar; crops such as beans, potatoes, avocados, mangoes, cherries; , and various grass species have been reported after spray applications of calcium fertilizers (Akhavankharazian et al. 1991; Anderson and Campbell 1995; Palta 1996; Percival et al. 1999). The practical implications of a hardiness gain of approximately $4^{\circ} \mathrm{C}\left(7.2^{\circ} \mathrm{F}\right)$ will depend heavily on geographic location. For example, within the United Kingdom, winters are in general characterized by a cool, wet growing season with temperatures rarely rising above $0^{\circ} \mathrm{C}\left(32^{\circ} \mathrm{F}\right)$. However, $5 \%$ of plants can be lost during production as a result of direct and indirect late frost injury in which temperatures as low as $-4^{\circ} \mathrm{C}$ $\left(25^{\circ} \mathrm{F}\right)$ have been recorded in late April and early May. Consequently, a hardiness gain of $4^{\circ} \mathrm{C}\left(7.2^{\circ} \mathrm{F}\right)$ would prove of value in relation to practical needs of the United Kingdom soft and top fruit, hardy ornamental stock, and bedding plant horticultural sectors (Cameron and Dixon 2000). Likewise, work by Raese (1996) concluded calcium spray-induced hardiness gains of $4^{\circ} \mathrm{C}$ $\left(7.2^{\circ} \mathrm{F}\right)$ improved yield and bud recovery of apple and pear trees located throughout the Pacific Northwest and may be sufficient to save a orchard crop of apple or pears.

The influence of calcium fertilization on improving the freezing tolerance of plant root systems has received little attention. In general, freezing damage to root systems of established trees is an uncommon phenomenon because root systems are, to a large degree, buffeted from major temperature fluctuation by the soil and mulch layer (Pellett 1971; Smit-Spinks et al. 1985). However, on occasion, arborists may be confronted with tree roots coming into direct contact with cold-conducting concrete structures such as sidewalks and roads, which add an additional element of predisposition concern. A similar situation may arise when the ground is surface-scraped under trees, removing the insulating soil layers (Randrup et al. 2001). Likewise, growing trees in planters, containers, and on rooftops exposes tree roots to low temperatures (Santamour 1979). Chilling damage to root systems is also a major problem of bare-rooted nursery, landscape, and forestry transplants during cold storage before planting out (McKay 1992, 1994). Freezing damage to roots is attributed to mechanical disruption of cell membranes caused by dehydration because extracellular ice crystals draw water from plant cells. Damage in turn is expressed aboveground as discoloration, bleaching, shrinkage, and dieback of foliar tissue (Kozlowski et al. 1991). Results of this study demonstrate a significant improvement in root freezing tolerance of both test species after calcium application as manifest by reduced electrolyte leakage values, as measures of membrane structural stability and cell wall strength, after a $-5^{\circ} \mathrm{C}\left(23^{\circ} \mathrm{F}\right)$ and $-6.5^{\circ} \mathrm{C}\left(20^{\circ} \mathrm{F}\right)$ treatment. Results of this study may, therefore, also be of pertinence in relation to needs of the forestry industry and producers of container-grown ornamental stock for the establishment and production of plants able to withstand greater freezing temperatures during the production and outplanting process.

A high correlation between twig and leaf tissue calcium content and the freezing temperature required to cause $50 \%$ electrolyte leakage was recorded in this study indicating the higher the internal tissue calcium content, the greater the tolerance to freezing. Improvements in the freezing tolerance of calcium-treated plants are achieved through alterations to the structural stability of cell walls and plasma membranes resulting from calcium links between phosphate and plasma lipids and a concomitant increase in physical cell wall strength (Legge et al. 1982). Calcium has also been implicated in controlling enzyme activity involved with freezing resistance. For example, cold temperatures increased levels of a calcium-dependent NAD kinase responsible for activating enzymes causing the synthesis of proteins necessary to influence the transcription of genes specific to cold acclimation. The progress of freezing injury can be also be halted by bathing or washing freeze-thaw-injured tissue in calciumbased solutions (Monroy et al. 1993; Berbezy et al. 1996). Electrolyte leakage is widely used to measure freezing damage through alterations in cell membrane structural integrity (McKay 1992; Percival and Galloway 1999). Reduced electrolyte leakage values in calcium-treated trees after freezing damage therefore indicate increased membrane structural stability and cell wall strength caused by calcium fertilization in both test species. Importantly, improvements in freezing and salinity tolerance were recorded approximately 3 to 5 months after the last calcium spray treatment. Such a result indicates at least 5 months enhanced freezing and salinity tolerance is conferred postcalcium treatment in both evergreen oak and apple.

Differences in the degree of freezing and salinity tolerance gained were noticeable between the calcium products used in this study. In general, calcium hydroxide, calcium nitrate borate, and calcium metalosate improved twig, leaf, and root freezing and salt tolerance of apple and evergreen oak to a greater degree than calcium chloride, calcium sulphate, calcium nitrate, and a calcium-magnesium complex. Because the total amount of calcium applied per tree was calibrated at $8 \mathrm{~g}(0.3 \mathrm{oz} ; 2 \mathrm{~g}[0.07 \mathrm{oz}]$ per spray, four sprays per tree), then this would indicate an important role for the anion, i.e., hydroxide, nitrate borate, metalosate, attached to the calcium ion. The positive influence of these anions may result from 1) a direct influence of the anion on freezing and salinity tolerance, 2) a positive synergistic interaction between calcium and the anion; 3) improved uptake of the calcium ion facilitated by the anion present; or 4) a combination of all three.

Metalosate is an amino acid-chelated calcium that is rapidly translocated into the phloem cells. Although a positive influence of select amino acids such as proline (Delauney and Verma 1993; Sieg et al. 1996; Thomashow 1999) and polyamines (putrescine, serotonin, spermidine) on the stress tolerance of plants is well documented (Shen et al. 2000), the influence of amino acids applied as a spray either singly or in combination with calcium is limited. Likewise, no positive role for hydroxide, sulphate, chloride, and magnesium alone on improving freezing tolerance of plants can be found. Field observations have suggested a link between enhanced leaf tissue damage in oilseed rape grown in low boron soils (Ye 2005). Likewise, chillinduced bleaching of young Eucalyptus urophylla leaves has been frequently observed in boron-deficient soils (Dell and Malajczuk 1994). In controlled experiments, exposure to $5^{\circ} \mathrm{C}$ $\left(41^{\circ} \mathrm{F}\right)$ significantly increased the electrolyte leakage in young leaves of Eucalyptus urophylla at a low boron supply $(5 \mu \mathrm{m})$, but not at higher $(15 \mu \mathrm{m})$ rates, indicating a positive role for boron in reducing chilling damage (Lu and Huang 2003). Nitrogenbased fertilizers have been shown to reduce plant tolerance to 
freezing by some authors, increase plant freezing tolerance by others, and neither decrease nor increase freezing tolerance (Proebstring 1961; Pellet and White 1969; Raesse 1997; Dehaynes et al. 1998; Smiley and Shirazi 2000). Further research is required to elucidate the influence of the anion attached to the calcium ion in influencing freezing and salinity tolerance of plants.

In conclusion, treatments with calcium sprays were associated with increased freezing and salinity hardiness to varying degrees in twig, leaf, and root tissue of apple and evergreen oak. The positive results for freezing and salt tolerance in these experiments should be considered noteworthy for individuals involved in tree management in areas subject to subzero temperature fluctuations and/or concomitant applications of deicing salts in the form of sodium chloride. However, although the hardiness gain of approximately $0.4^{\circ} \mathrm{C}$ to $4.3^{\circ} \mathrm{C}\left(0.72^{\circ} \mathrm{F}\right.$ to $\left.7.7^{\circ} \mathrm{F}\right)$ reported in this study may prove important for saving trees in some circumstances, the degree of protection conferred may not be sufficient during extreme winter-injury years (Raese 1997).

Acknowledgments. We are grateful for funding from the TREE Fund (John Z. Duling). Helpful comments from Dr. Tom Smiley, Bartlett Tree Research Laboratory, Charlotte, North Carolina, are also appreciated.

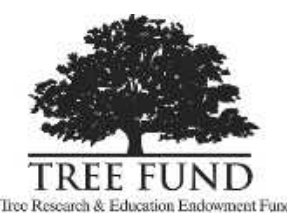

\section{LITERATURE CITED}

Akhavankharazian, M., W.F. Campbell, J.J. Jurinak, and L.M. Dudley. 1991. Calcium amelioration of $\mathrm{NaCl}$ effects on plant growth, chlorophyll and ion concentration in Phaseolus vulgaris. Arid Soil Research and Rehabilitation 5:9-19.

Anderson, J.L., and W.F. Campbell. 1995. Calcium transport and ATPase activity in microsomal vesicle fraction from 'Montmorency' sour cherry fruit. Acta Horticulturae 398:47-57.

Anon. 2007. Cold wave may cost California's citrus industry $\$ 1$ billion. International Herald Tribune, Bloomberg News, The Associated Press. January 18.16 pp.

Berbezy, P., L. Legendre, and A. Maujean. 1996. Purification and characterisation of alpha-amylase from vine shoot inter-nodes. Plant Physiology and Biochemistry 34:353-361.

Cameron, R.W.F., and G.R. Dixon. 2000. The influence of temperature, daylength and calendar date on cold tolerance Rhododendron. The Journal of Horticultural Science and Biotechnology 75:481-487.

Cannel, M.G.R., and R.I. Smith. 1986. Climatic warming, spring budburst and frost damage on trees. Journal of Applied Ecology 23: 177-191.

Dehaynes, D.H., M.A. Ingle, and C.E. White. 1998. Nitrogen fertilization enhances cold tolerance of red spruce seedlings. Canadian Journal of Forestry Research 19:1037-1043.

Delauney, A.J., and D.P.S. Verma. 1993. Proline biosynthesis and osmoregulation in plants. The Plant Journal 4:215-223.

Dell, B., and N. Malajczuk. 1994. Boron deficiency in eucalypt plantations in China. Canadian Journal of Forest Research 24:2409-2416.

Dobson, M.C. 1991. De-icing Salt Damage to Trees and Shrubs. Forestry Commission Bulletin 101.

Greaves, J.A., and J.M. Wilson. 1987. Chlorophyll fluorescence analysis-An aid to plant breeders. Biologist (Columbus, Ohio) 34: 209-214.

Kozlowski, T.T., P.J. Kramer, and S.G. Pallardy. 1991. The Physiological Ecology of Woody Plants. Academic Press, San Diego, CA.

Legge, R.L., E. Thompson, J.E. Baker, and M. Lieberman. 1982. The effect of calcium on the fluidity and phase properties of microsomal membranes isolated from post climacteric Golden Delicious apples. Plant and Cell Physiology 23:161-169.
Levene, H. 1960. Robust tests for equality of variances. In Olkin, I., S.G. Ghurye, W. Hoeffding, W.G. Madow, and H.B. Mann (Eds.). Contributions to Probability and Statistics. Stanford University Press, Stanford, CA.

Lu, C., and B. Huang. 2003. Effects of boron on membrane lipid peroxidation and endogenous protective systems in leaves of Eucalyptus grandis $\times$ Eucalyptus urophylla under low temperature. Journal of Tropical and Subtropical Botany 11:217-222.

McKay, H. 1992. Electrolyte leakage from fine roots of conifer seedlings: A rapid index of plant vitality following cold storage. Canadian Journal of Forestry Research 22:1371-1377.

- 1994. Frost hardiness and cold-storage tolerance of the root system of Picea sitchensis, Pseudotsuga menziesii, Larix kaempferi and Pinus sylvestris bare-root seedlings. Scandinavian Journal of Forestry Research 9:203-213.

Meinander, O., S. Somersalo, T. Holopainen, and R.J. Strasser. 1996. Scots Pine after exposure to elevated ozone and carbon dioxide probed by reflectance spectra and chlorophyll a fluorescence transients. Journal of Plant Physiology 148:229-236.

Monroy, A.F., F. Sarhan, and R.S. Dhindsa. 1993. Cold-induced changes in freezing tolerance, protein phosphorylation, and gene expression. Plant Physiology 102:1227-1235.

Nicholas, A.H., R. Spooner-Hart, and R.A. Vickers. 2003. Control of woolly aphid, Eriosoma lanigerum (Hausmann) (Hemiptera: Pemphigidae) on mature apple trees using insecticide soil-root drenches. Australian Journal of Entomology 42:6-11.

Palta, J.P. 1996. Role of calcium in plant responses to stresses: Linking basic research to the solution of practical problems. HortScience 31:51-57.

Palta, J.P., and P.H. Li. 1980. Alterations in membrane transport properties by freezing injury in herbaceous plants. Evidence against rupture theory. Physiologia Plantarum 50:169-175.

Pellet, N.E., and D.B. White. 1969. Effects of soil nitrogen and soil moisture levels on cold acclimation of container grown Juniperus chinensis 'Hetsi'. Journal of the Americian Society of Horticultural Science. 94:457-459.

Pellett, H. 1971. Comparison of cold hardiness levels of root and stem tissue. Canadian Journal of Plant Science 22:1371-1377.

Percival, G.C., and S. Barnes. 2005. Auxins and water-retaining polymer root dips affect survival and growth of newly transplanted barerooted European beech and silver birch. Journal of Environmental Horticulture 22:183-189.

Percival, G.C., C. Boyle, and L. Baird. 1999. The influence of calcium supplementation on the freezing tolerance of woody plants. Journal of Arboriculture 25:285-291.

Percival, G.C., G.A. Fraser, and G. Oxenham. 2003. Foliar salt tolerance of Acer genotypes using chlorophyll fluorescence. Journal of Arboriculture 29:61-66.

Percival, G.C., and A. Galloway. 1999. The potential of chlorophyll fluorescence measurements to detect salt and waterlogging stress in urban trees. Acta Horticulturae 496:253-259.

Percival, G.C., and J. Hitchmough. 1995. Tree establishment and performance in a cool growing season arboretum. Arboricultural Journal 19:357-371.

Proebstring, E.L. 1961. Cold hardiness of Elberta peach fruit buds as influenced by nitrogen level and cover crop. Proceedings of the American Society of Horticultural Science 77:97-106.

Raese, J.T. 1996. Winter hardiness increased with calcium treatments. Good Fruit Grower 47:41-48.

. 1997. Cold tolerance, yield and fruit quality of d'Anjou pears influenced by nitrogen fertilizer rates and time of application. Journal of Plant Nutrition 20:1007-1025.

Randrup, T.B., E.G. McPherson, and L.R. Costello. 2001. A review of tree conflicts with sidewalks, curbs and roads. Urban Ecosystems 5:209-225.

Sakai, A., and W. Larcher. 1987. Frost Survival of Plants. Responses and Adaptations to Freezing Stress. Springer-Verlag, London, UK. 
Santamour, F.S. Jr. 1979. Root hardiness of green ash seedlings from different provenances. Journal of Arboriculture 15:276-279.

Shen, W., K. Nada, and S. Tachibana. 2000. Involvement of polyamines in the chilling tolerance of cucumber cultivars. Plant Physiology 124: 431-439.

Sieg, F., W. Schroder, J.M. Schmitt, and D.K. Hincha. 1996. Purification and characterization of a cryoprotective protein (cryoprotection) from the leaves of cold-acclimated cabbage. Plant Physiology 111: 215-221.

Smiley, E.T., and A.M. Shirazi. 2000. Fall fertilization and winter hardiness, pp. 93-103. Proceedings from an International Conference on Tree and Shrub Fertilization, May 17-18, 2000, Fairlawn, OH.

Smit-Spinks, B., B. Swanson, and A.H. Markhart III. 1985. The effects of photoperiod and thermoperiod on cold acclimation and growth of Pinus sylvestris. Canadian Journal of Forestry Research 15:453-460.

Steponkus, P.L. 1984. Role of the plasma membrane in freezing injury and cold acclimation. Annual Review of Plant Physiology 35: 543-584.

Thomashow, M.F. 1999. Freezing tolerance genes and regulatory mechanisms. Annual Review of Plant Physiology and Plant Molecular Biology 50:571-599.

Willits, D.H., and M.M. Peet. 2001. Using chlorophyll fluorescence to model leaf photosynthesis in greenhouse pepper and tomato. Acta Horticulturae 507:311-315.

Ye, Z. 2005. Effect of low temperature on plant boron nutrition. Murdoch University, PhD Diss.

Glynn Percival (corresponding author)

Bartlett Tree Research Laboratory

Plant Science Laboratories

School of Biological Sciences

Whiteknights

University of Reading

Reading, Berkshire, RG6 6AS, U.K.

gpercival@bartlettuk.com

\section{Sally Barnes}

School of Biology

University of Nottingham

University Park

Nottingham, NG7 2RD, U.K.

Résumé. Une plus grande variabilité dans les patrons climatiques et des gels plus tardifs au printemps équivalent à une faible rusticité face à l'hiver, une éclosion printanière prématurée des bourgeons et une plus grande susceptibilité aux dommages par les températures basses ainsi que l'application concomitante de sel de déglaçage. Un essai sur le terrain a été conduit pour déterminer l'influence d'une variété de fertilisants commerciaux à base de calcium appliqués par vaporisation foliaire en regard de la tolérance au gel et au sel de deux espèces d'arbres, le chêne à feuilles de houx (Quercus ilex L.) et le pommier (Malus cv. Golden Crown). Dans tous les cas, les applications foliaires de calcium ont augmenté la tolérance au froid et au sel des pousses, des feuilles et des racines pour les deux espèces tel que mesuré par la fluorescence de la chlorophylle ainsi que les bio-essais dans les tissus de rejet d'électrolytes. Dans le cas du pommier, le gain en rusticité enregistré dans les tissus foliaires était de $4,3^{\circ} \mathrm{C}$. Dans le cas du chêne à feuilles de houx, le gain en rusticité était de $2,1^{\circ} \mathrm{C}$. Suite à un stress de refroidissement de $-5^{\circ} \mathrm{C}$ pour le pommier et de $-6,5^{\circ} \mathrm{C}$ pour le chêne à feuilles de houx, les valeurs de rejet d'électrolytes en tant que mesure de dommage structural à la membrane cellulaire étaient de 16 à $27 \%$ en moins pour les arbres traités avec le calcium par rapport à ceux du groupe témoin. La concentration en sel requise pour causer des réductions de $50 \%$ en fluorescence de la chlorophylle, et ce en tant que mesure de l'efficience photosynthétique, a augmenté de 0,2 à $1,2 \%$ chez les arbres traités avec le calcium, ce qui indique une influence positive du calcium pour augmenter la tolérance des tissus foliaires face aux dommages par le sel. Des différences dans la magnitude des gains en tolérance face au froid et au sel étaient notables entre les différents produits en calcium utilisés. En général, l'hydroxyde de calcium, le borate-nitrate de calcium et le metalosate de calcium amélioraient à un degré plus élevé la tolérance au froid et au sel des pousses, des feuilles et des racines des deux espèces, et ce par rapport au chlorure de calcium, au sulfate de calcium, au nitrate de calcium et au complexe magnésoium-calcium. Une corrélation significative existait entre l'accroissement de la tolérance au froid et le contenu foliaire interne en calcium. Les résultats de cette étude indiquent que les vaporisations foliaires en calcium tard en été et en automne peuvent accroître la tolérance au froid et au sel du chêne à feuilles de houx et du pommier durant la période hivernale. Ceci devrait être considéré avec attention par ceux impliqués dans la gestion des arbres au sein de milieux urbains soumis à des fluctuations de températures sous zéro et/ou avec des applications concomitantes de sel de déglaçage sous la forme de chlorure de sodium.

Zusammenfassung. Größere Variablität der Wetterphänomene und späte Frühjahrsfröste führen zu schlechter Winterhärte, vorzeitigem Knospentrieb und größerer Anfälligkeit gegenüber niedrigen Temperaturen und Streusalz-Applikationen. Es wurde ein Feldversuch unternommen, um den Einfluss einer Reihe von kommerziell erhältlichen und als Spray applizierten Kalziumdüngern auf die Frost- und Salztoleranz von zwei Spezies, Immergrüne Eiche und Apfel, zu bestimmen. In allen Fällen verbesserte die Kalziumapplikation, gemessen als Blattchlorophyll-Fluoreszenz und Elektrolytaustritt des Gewebes bei beiden Arten die Frost- und Salztoleranz von Zeigen, Blättern und Wurzeln. Beim Apfel wurde die Frosthärte um $4,3^{\circ} \mathrm{C}$ im Zweiggewebe gemessen. Bei der Immergrünen Eiche wurde in den Blättern eine gesteigerte Toleranz von $2,1^{\circ} \mathrm{C}$ verzeichnet. Nach einem Froststress von $-5^{\circ} \mathrm{C}$ beim Apfel und $-6,5^{\circ} \mathrm{C}$ bei der Immergrünen Eiche war der Elektrolytaustritt als ein $\mathrm{Ma}$ von Zellmembranzerstörung in kalziumbehandelten Bäumen um 16-27\% geringer als bei unbehandelten Bäumen. Die erforderliche Salzkonzentration für eine 50\%ige Reduktion der BlattchlorophyllFluoreszenz als ein $\mathrm{Ma}$ für die Photosynthese-Effizienz stieg bei kalziumbehandelten Bäumen um 0,2-1,2 \%, was den positiven Einfluss von Kalzium zur Verbesserung der Salztoleranz der Blätter verdeutlicht. Zwischen den verschiedenen Kalziumdüngern konnten Unterschiede in der Höhe der Salz- und Frosttoleranz gemessen werden. Allgemein verbesserten Kalziumhydroxid, Kalziumnitrat und Kalziummetalosat die Salz- und Frosttoleranz der Zweige, Blätter und Wurzeln bei beiden Arten zu einem größeren Anteil als Kalziumchlorid, Kalziumsulfat, Kalziumnitrat und ein Kalzium-Magnesiumkomlex. Es bestand eine signifikante Korrelation zwischen verstärkter Frosttoleranz und Gewebeinternem Kalziumgehalt. Die Ergebnisse dieser Studie zeigten, dass Kalziumsprays während des späten Sommers und Herbst die Salz- und Frosttoleranz bei Immergrünen Eichen und Apfel während der Winterperiode verbessern. Das sollte Personen, die in das Management von Bäumen in Gegenden mit Minustemperaturen und/oder Streusalzapplikationen in Form von Sodiumchlorid involviert sind, bekannt gemacht werden.

Resumen. La gran variabilidad en los patrones del clima y heladas tardías son equiparables a una pobre resistencia invernal, rompimiento prematuro de yemas y mayor susceptibilidad a daño por bajas temperaturas y la concomitante aplicación de sales descongelantes. Se realizó un ensayo de campo para determinar la influencia de un rango de fertilizantes comercialmente disponibles a base de calcio, aplicados como aerosoles foliares, sobre la tolerancia al congelamiento y salinidad de dos especies de árboles: encino siempreverde (Quercus ilex L.) y manzano (Malus cv. Golden Crown). En todos los casos la aplicación de aerosoles de calcio incrementó los brotes, la tolerancia al congelamiento y sales, de ambas especies, medidos como fluorescencia de clorofila y bioensayos de electrolitos. En el caso del manzano, una ganancia en resistencia de $4.3^{\circ} \mathrm{C}\left(7.74^{\circ} \mathrm{F}\right)$ se registró en el tejido de los brotes. En el 
caso del encino una ganancia de $2.1^{\circ} \mathrm{C}\left(3.78^{\circ} \mathrm{F}\right)$ se registró en el tejido. Después de $-5^{\circ} \mathrm{C}\left(23^{\circ} \mathrm{F}\right)$ (manzano) y $-6.5^{\circ} \mathrm{C}\left(20^{\circ} \mathrm{F}\right)$ (encino) los valores del estrés al congelamiento y electrolitos en la raíz, como una medida del daño estructural en la membrana celular, fueron 16-27\% menores en los árboles tratados con calcio, comparados con los controles no tratados. La concentración de sal necesaria para causar reducciones del 50\% en fluorescencia de clorofila, como una medida de la eficiencia fotosintética, estuvo en $0.2-1.2 \%$ en árboles fertilizados con calcio, indicando la influencia positiva del calcio en el realce de la tolerancia del tejido foliar al daño por sales. Las diferencia en la magnitud de la tolerancia al enfriamiento y salinidad fueron notables entre los productos empleados con calcio. En general, el hidróxido de calcio, el borato nitrato de calcio y metalosato de calcio mejoraron la tolerancia al congelamiento y a las sales de los brotes y raíces en ambas especies de árboles; a un mayor grado que cloruro de calcio, sulfato, nitrato de calcio y un complejo magnesio-calcio. Existió una correlación significativa entre el incremento a la tolerancia al enfriamiento y el contenido de calcio en los tejidos internos. Los resultados de este estudio indican que los aerosoles de calcio durante el verano tardío y otoño pueden incrementar la tolerancia al congelamiento y salinidad de encino siempreverde y manzano durante el periodo invernal. Esto debería ser considerado para individuos envueltos en el manejo de árboles en áreas sujetas a fluctuaciones de temperatura bajo cero y/o aplicaciones concomitantes de sales descongelantes en forma de cloruro de sodio. 